\title{
Freedom, Trade, and Growth
}

\author{
Joshua A. Byrge and Michael R. Pakko
}

$\mathbf{F}$ or over a decade, the Heritage Foundation and the Wall Street Journal have published an annual Index of Economic Freedom, ranking countries around the world using a set of ten objective economic criteria. On a scale from 1 to 5 , a country is considered "free" if its average score is less than 2, "mostly free" if between 2 and 2.99, "mostly unfree" if between 3 and 3.99, and "repressed" if its score is 4 or greater. (See Table 1.) One of the ten categories included in the Index of Economic Freedom is a measure of openness to trade. The rankings of countries for this particular variable are closely related to their rankings in the overall index.

The trade measure is based on a country's weighted average tariff rate, with the weights based on imports from the country's trading partners. The best score (1) is given if a country's weighted average tariff rate is less than 2.5 percent. The worst score (5) is given to countries with a weighted average tariff rate greater than 20 percent. One point is also added to a country's trade score when there is evidence of significant non-tariff barriers.

Of the 157 countries given a trade score in the 2006 index, only two-Singapore and Hong Kong-received the top grade. These two countries were also the top two countries in the overall index score. Of the 18 countries receiving the worst score on trade, 16 fell into the categories of "mostly unfree" or "repressed" in the overall results.

The measure of trade-openness used in the index, based on tariff rates, contrasts with alternative measures of trade policy that are related to the volume of trade. For example, the Penn World Tables includes a measure called "openness," which is calculated as the sum of exports and imports divided by gross domestic product. These two measures-one based on policies and the other based on trade outcomes-yield similar rankings among countries. The 37 countries receiving a score of 2 or better in the index had an average openness score of 108 in the Penn World Tables. The 49 countries receiving a score of 4 or worse in the index had an openness score of only 75 in the Penn World Tables.

Openness to trade and other measures of economic freedom are important not only for their direct benefits, but also because they indicate a more general propensity to follow economic policies that foster growth and development. For example, Table 2 shows that those countries that moved toward freer trade over time have grown faster than those who have moved toward more restrictive trade policies. The 79 countries that improved their trade policy score between 1997 and 2006 showed an average

growth rate of 2.5 percent, while the 28 countries whose trade scores declined grew at an average rate of only 1.8 percent.

Table 2 also subdivides each of these categories into categories related to the overall index. This breakdown shows the complementarity between open trade and economic freedom in general. In each category (trade policy rising or falling) those countries that are "free" or "mostly free" showed higher growth rates than those that are "mostly unfree" or "repressed." The more economic freedom displayed by the policies of a country, the better its residents can respond to more open trade.

Table 1. Economic Freedom Index, 2006

\begin{tabular}{llll}
\multicolumn{1}{c}{$\begin{array}{c}\text { "Free" } \\
\text { (top six) }\end{array}$} & \multicolumn{2}{c}{$\begin{array}{c}\text { "Repressed" } \\
\text { (bottom six) }\end{array}$} \\
\hline Hong Kong & 1.28 & North Korea & 5.00 \\
Singapore & 1.56 & Iran & 4.51 \\
Ireland & 1.58 & Burma (Myanmar) & 4.46 \\
Luxembourg & 1.60 & Zimbabwe & 4.23 \\
Iceland & 1.74 & Libya & 4.16 \\
United Kingdom & 1.74 & Venezuela & 4.16
\end{tabular}

SOURCE: Heritage Foundation/Wall Street Journal's Index of Economic Freedom, 2006.

Table 2. Trade Policy and Growth

\begin{tabular}{lr}
$\begin{array}{l}\text { Changes in trade policy score } \\
\text { (2006 vs. 1997) }\end{array}$ & $\begin{array}{r}\text { Percent re } \\
\text { per capita } \\
\text { (1995-2 }\end{array}$ \\
\hline Improved (79 countries) & 2.49 \\
"Free" or "mostly free" & 2.80 \\
"Mostly unfree" or "repressed" & 2.15 \\
Declined (28 countries) & 1.80 \\
"Free" or "mostly free" & 2.21 \\
"Mostly unfree" or "repressed" & 1.53
\end{tabular}

SOURCE: Heritage Foundation/Wall Street Journal's Index of Economic Freedom, 1997 and 2006; Penn World Tables, Volume 6.2; and authors' calculations. 